\title{
Clofazimine Induced Suicidal Death of Human Erythrocytes
}

\author{
Arbace Officioso ${ }^{a, b}$ Kousi Alzoubia Caterina Manna ${ }^{b}$ Florian Lang ${ }^{a}$ \\ aDepartment of Physiology, University of Tübingen, Tübingen, Germany; ' ${ }^{\circ}$ Department of Biochemistry, \\ Biophysics and General Pathology, School of Medicine, Second University of Naples, Naples, Italy
}

\section{Key Words}

Phosphatidylserine $\cdot \mathrm{Ca}^{2+} \cdot$ Phospholipase $\mathrm{A}_{2} \cdot \mathrm{ATP} \cdot$ Eryptosis

\begin{abstract}
Background/Aims: The antimycobacterial riminophenazine clofazimine has previously been shown to up-regulate cellular phospholipase $A_{2}$ and to induce apoptosis. In erythrocytes phospholipase $A_{2}$ stimulates eryptosis, the suicidal erythrocyte death characterized by cell shrinkage and cell membrane scrambling with phosphatidylserine translocation to the erythrocyte surface. Phospholipase $\mathrm{A}_{2}$ is in part effective by fostering formation of prostaglandin $\mathrm{E}_{2}$, which triggers $\mathrm{Ca}^{2+}$ entry. Stimulators of $\mathrm{Ca}^{2+}$ entry and eryptosis further include oxidative stress and energy depletion. The present study tested, whether and how clofazimine induces eryptosis. Methods: Phosphatidylserine exposure at the cell surface was estimated from annexin $\mathrm{V}$ binding, cell volume from forward scatter, hemolysis from hemoglobin release, cytosolic $\mathrm{Ca}^{2+}$ activity $\left(\left[\mathrm{Ca}^{2+}\right]_{\mathrm{i}}\right.$ ) from Fluo3-fluorescence, reactive oxygen species (ROS) from $2^{\prime}, 7^{\prime}$-dichlorodihydrofluorescein diacetate (DCFDA) fluorescence, and cytosolic ATP level utilizing a luciferin-luciferase assay kit. Results: A 24-48 hours exposure of human erythrocytes to clofazimine $(\geq 1.5 \mathrm{\mu g} / \mathrm{ml})$ significantly increased the percentage of annexin-V-binding cells without appreciably modifying forward scatter. Clofazimine significantly increased $\left[\mathrm{Ca}^{2+}\right]_{i^{\prime}}$ significantly decreased cytosolic ATP, but did not significantly modify ROS. The effect of clofazimine on annexin-V-binding was significantly blunted, but not fully abolished by removal of extracellular $\mathrm{Ca}^{2+}$, and by phospholipase $\mathrm{A}_{2}$ inhibitor quinacrine $(25 \mu \mathrm{M})$. Clofazimine further augmented the effect of $\mathrm{Ca}^{2+}$ ionophore ionomycin $(0.1 \mu \mathrm{M})$ on eryptosis. The clofazimine induced annexin-V-binding was, however, completely abrogated by combined $\mathrm{Ca}^{2+}$ removal and addition of quinacrine. Conclusion: Clofazimine stimulates phospholipid scrambling of the erythrocyte cell membrane, an effect in part dependent on entry of extracellular $\mathrm{Ca}^{2+}$, paralleled by cellular energy depletion and sensitive to phospholipase $A_{2}$ inhibitor quinacrine.
\end{abstract}

Copyright $@ 2015$ S. Karger AG, Basel

\section{Introduction}

The riminophenazine antibiotic clofazimine is used for the treatment of mycobacterial infections including but not limited to leprosy and drug resistant tuberculosis [1-13]. Clofazimine has further anti-inflammatory potency and is considered for the treatment of 


\section{Cellular Physiology Cell Physiol Biochem 2015;37:331-341 \begin{tabular}{l|l|l}
\hline DOI: 10.1159/000430357 & C 2015 S. Karger AG, Basel
\end{tabular} \begin{tabular}{l|l} 
and Biochemistry Published online: August 24, 2015 & www.karger.com/cpb
\end{tabular}

several inflammatory disorders including psoriasis and autoimmune disease $[1,4,6,8,14]$. Its use is, however, limited by its toxicity [15].

Clofazimine may create intracellular crystal-like drug inclusions [16] and intercalate into bacterial DNA [1]. Clofazimine-sensitive cellular mechanisms further include mitochondrial deplarisation [16], up-regulation of cellular phospholipase $A_{2}$ [1], caspase activation [17], and induction of apoptosis $[16,18]$.

Phospholipase $A_{2}$ activity with subsequent formation of prostaglandin $E_{2}$ [19] may lead to eryptosis, the suicidal death of erythrocytes characterized by cell shrinkage [20] and cell membrane scrambling with phosphatidylserine translocation to the cell surface [21]. PGE is effective by stimulating $\mathrm{Ca}^{2+}$ entry with increase of cytosolic $\mathrm{Ca}^{2+}$ activity $\left(\left[\mathrm{Ca}^{2+}\right]_{\mathrm{i}}\right)[21]$. $\mathrm{Ca}^{2+}$ entry may, in addition, be triggered by oxidative stress [21]. Further cellular mechanisms fostering eryptosis include ceramide [22], energy depletion [21], as well as activated caspases $[21,23,24]$, casein kinase $1 \alpha$, Janus-activated kinase JAK3, protein kinase C, and p38 kinase, [21]. Eryptosis is inhibited by AMP activated kinase AMPK, cGMP-dependent protein kinase, PAK2 kinase, and sorafenib/sunitinib sensitive kinases [21]. A wide variety of xenobiotics have been shown to activate or inhibit eryptosis [21, 25-53].

The present study explored, whether and, if so, how clofazimine triggers eryptosis. To this end, human erythrocytes from healthy volunteers were treated with clofazimine and phosphatidylserine surface abundance and cell volume determined by flow cytometry.

\section{Materials and Methods}

\section{Erythrocytes, solutions and chemicals}

Fresh Li-Heparin-anticoagulated blood samples were kindly provided by the blood bank of the University of Tübingen. The study is approved by the ethics committee of the University of Tübingen $(184 / 2003 \mathrm{~V})$. The blood was centrifuged at $120 \mathrm{~g}$ for $20 \mathrm{~min}$ at $21^{\circ} \mathrm{C}$ and the platelets and leukocytes-containing supernatant was disposed. Erythrocytes were incubated in vitro at a hematocrit of $0.4 \%$ in Ringer solution containing (in mM) $125 \mathrm{NaCl}, 5 \mathrm{KCl}, 1 \mathrm{MgSO}_{4}, 32 \mathrm{~N}$-2-hydroxyethylpiperazine-N-2-ethanesulfonic acid (HEPES), 5 glucose, $1 \mathrm{CaCl}_{2} ; \mathrm{pH} 7.4$ at $37^{\circ} \mathrm{C}$ for $24 \mathrm{~h}$. In $\mathrm{Ca}^{2+}$ free solutions, $\mathrm{Ca}^{2+}$ was was removed without replacement. The high buffer capacity (32 HEPES) was used in order to prevent appreciable $\mathrm{pH}$ changes despite lactate formation by erythrocytes. Where indicated, erythrocytes were exposed to clofazimine (Sigma Aldrich, Hamburg, Germany), or quinacrine (Sigma Aldrich, Hamburg, Germany) at the indicated concentrations.

\section{Annexin-V-binding and forward scatter}

After incubation under the respective experimental condition, $150 \mu \mathrm{l}$ cell suspension was washed in Ringer solution containing $5 \mathrm{mM} \mathrm{CaCl}_{2}$ and then stained with Annexin-V-FITC (1:200 dilution; ImmunoTools, Friesoythe, Germany) in this solution at $37^{\circ} \mathrm{C}$ for $20 \mathrm{~min}$ under protection from light. The annexin $V$ abundance at the erythrocyte surface was subsequently determined on a FACS Calibur (BD, Heidelberg, Germany). A dot plot of forward scatter (FSC) vs. side scatter (SSC) was set to linear scale for both parameters. The threshold of forward scatter was set at the default value of " 52 ".

\section{Hemolysis}

For the determination of hemolysis, the samples were centrifuged (10 min at $2000 \mathrm{rpm}$, room temperature) after incubation under the respective experimental conditions and the supernatants were harvested. As a measure of hemolysis, the hemoglobin $(\mathrm{Hb})$ concentration of the supernatant was determined photometrically at $405 \mathrm{~nm}$. The absorption of the supernatant of erythrocytes lysed in distilled water was defined as $100 \%$ hemolysis.

Intracellular $\mathrm{Ca}^{2+}$

After incubation, erythrocytes were washed in Ringer solution and then loaded with Fluo-3/AM (Biotium, Hayward, USA) in Ringer solution containing $5 \mu \mathrm{M}$ Fluo-3/AM. The cells were incubated at $37^{\circ} \mathrm{C}$ for $30 \mathrm{~min}$ and washed twice in Ringer solution containing $5 \mathrm{mM} \mathrm{CaCl}_{2}$. The Fluo-3/AM-loaded erythrocytes 


\section{Cellular Physiology Cell Physiol Biochem 2015;37:331-341 \begin{tabular}{l|l|l}
\hline DOI: 10.1159/000430357 & (C) 2015 S. Karger AG, Basel
\end{tabular} \begin{tabular}{l|l|l|l|l} 
and Biochemistry Published online: August 24, 2015 & www.karger.com/cpb
\end{tabular} \\ Officioso/Alzoubi/Manna/Lang: Clofazimine-Induced Eryptosis}

were resuspended in $200 \mu \mathrm{l}$ Ringer. Then, $\mathrm{Ca}^{2+}$-dependent fluorescence intensity was measured with an excitation wavelength of $488 \mathrm{~nm}$ and an emission wavelength of $530 \mathrm{~nm}$ on a FACS Calibur.

Reactive oxygen species (ROS)

Oxidative stress was determined utilizing 2',7'-dichlorodihydrofluorescein diacetate (DCFDA). After incubation, a $100 \mu \mathrm{l}$ suspension of erythrocytes was washed in Ringer solution and then stained with DCFDA (Sigma, Schnelldorf, Germany) in Ringer solution containing DCFDA at a final concentration of 10 $\mu \mathrm{M}$. Erythrocytes were incubated at $37^{\circ} \mathrm{C}$ for $30 \mathrm{~min}$ in the dark and then washed three times in Ringer solution. The DCFDA-loaded erythrocytes were resuspended in $200 \mu$ l Ringer solution, and ROS-dependent fluorescence intensity was measured at an excitation wavelength of $488 \mathrm{~nm}$ and an emission wavelength of $530 \mathrm{~nm}$ on a FACS Calibur (BD).

\section{Intracellular ATP levels}

For the determination of intracellular erythrocyte ATP, $80 \mu \mathrm{l}$ of erythrocyte pellets were incubated for $24 \mathrm{~h}$ at $37^{\circ} \mathrm{C}$ in Ringer solution with or without clofazimine $(1.5 \mu \mathrm{g} / \mathrm{ml})$. All subsequent manipulations were performed at $4{ }^{\circ} \mathrm{C}$ to avoid ATP degradation. Cells were lysed in distilled water, and proteins were precipitated by addition of $\mathrm{HClO}_{4}(5 \%)$. After centrifugation (Eppendorf Microcentrifuge 5417R, Hamburg, Germany) at $2000 \mathrm{rpm}$ for 5 min the erythrocytes were washed once in PBS and centrifuged again. An aliquot of the supernatant $(400 \mu \mathrm{l})$ was adjusted to $\mathrm{pH} 7.7$ by addition of saturated $\mathrm{KHCO}_{3}$ solution. After dilution of the supernatant, the ATP concentrations of the aliquots were determined utilizing a luciferinluciferase assay kit (Roche Diagnostics) on a luminometer (Berthold Biolumat LB9500, Bad Wildbad, Germany) according to the manufacturer's protocol.

\section{Statistics}

Data are expressed as arithmetic means \pm SEM. As indicated in the figure legends, statistical analysis was made using ANOVA with Tukey's test as post-test and $t$ test as appropriate. $\mathrm{n}$ denotes the number of different erythrocyte specimens studied. Since different erythrocyte specimens used in distinct experiments are differently susceptible to triggers of eryptosis, the same erythrocyte specimens have been used for control and experimental conditions.

\section{Results}

The present study explored the effect of clofazimine on eryptosis, the suicidal erythrocyte death. The most important hallmark of eryptosis is cell membrane scrambling with phosphatidylserine translocation to the cell surface. Phosphatidylserine exposing erythrocytes were identified utilizing annexin-V-binding, as determined by flow cytometry. The erythrocytes were analysed following incubation for 24 or 48 hours in Ringer solution without or with clofazimine $(1.5-7.5 \mu \mathrm{g} / \mathrm{ml})$. As shown in Fig. 1 exposure to clofazimine increased the percentage of annexin-V-binding erythrocytes, an effect reaching statistical significance at $7.5 \mu \mathrm{g} / \mathrm{ml}$ after 24 hours and at $1.5 \mu \mathrm{g} / \mathrm{ml}$ after 48 hours.

In order to quantify hemolysis, the hemoglobin concentration in the supernatant was determined by photometry. As shown in Fig. 1D, a 48 hours incubation with clofazimine 1.5 $-7.5 \mu \mathrm{g} / \mathrm{ml}$ ) slightly increased hemolysis, an effect reaching statistical significance at $7.5 \mu \mathrm{g} /$ $\mathrm{ml}$.

Eryptosis is typically paralleled by cell shrinkage. In order to estimate cell volume, forward scatter was determined utilizing flow cytometry. As a result, the forward scatter was similar following a 24 hours incubation without $(461 \pm 12, \mathrm{n}=4)$ and with $1.5 \mu \mathrm{g} / \mathrm{ml}$ $(461 \pm 15, \mathrm{n}=4)$ or $7.5 \mu \mathrm{g} / \mathrm{ml}(462 \pm 16, \mathrm{n}=4)$ clofazimine. Moreover, the forward scatter was similar following a 48 hours incubation without $(446 \pm 9, \mathrm{n}=4)$ and with $1.5 \mu \mathrm{g} / \mathrm{ml}(461$ $\pm 10, \mathrm{n}=4)$ or $7.5 \mu \mathrm{g} / \mathrm{ml}(453 \pm 9, \mathrm{n}=4)$ clofazimine.

In order to determine whether clofazimine modifies cytosolic $\mathrm{Ca}^{2+}$ activity $\left(\left[\mathrm{Ca}^{2+}\right]_{\mathrm{i}}\right)$, Fluo3 fluorescence was taken as measure of $\left[\mathrm{Ca}^{2+}\right]_{\mathrm{i}^{*}}$ As illustrated in Fig. 2, a 48 hours exposure to clofazimine ( 1.5 and $7.5 \mu \mathrm{g} / \mathrm{ml})$ significantly increased the Fluo3 fluorescence. 


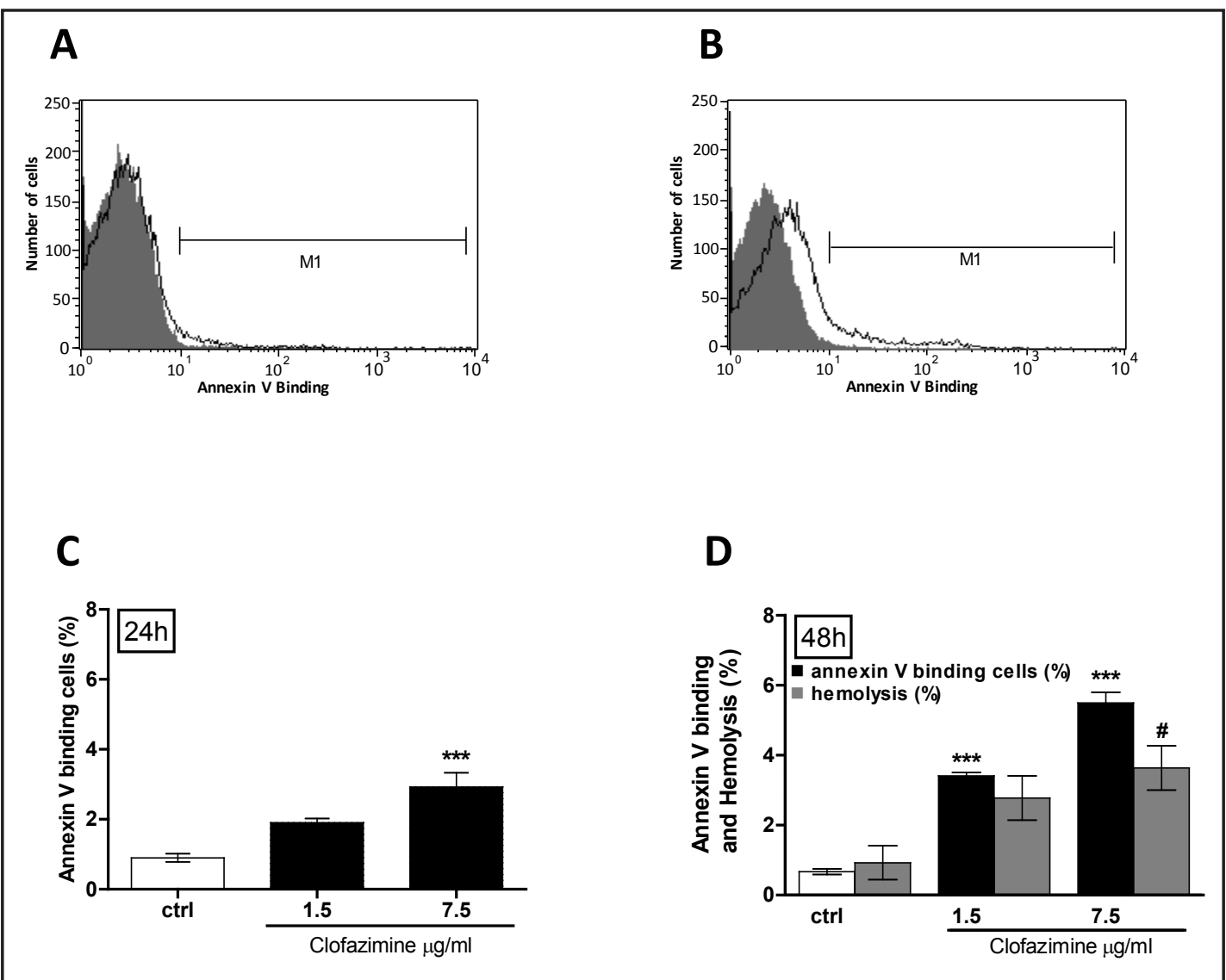

Fig. 1. Effect of clofazimine on phosphatidylserine exposure. A,B. Original histogram of annexin-V-binding of erythrocytes following exposure for 24 hours (A) or 48 hours (B) to Ringer solution without (grey areas) and with (black lines) presence of $1.5 \mu \mathrm{g} / \mathrm{ml}$ clofazimine . C,D. Arithmetic means \pm SEM $(n=4)$ of erythrocyte annexin-V-binding following incubation for 24 hours (C) or 48 hours (D) to Ringer solution without (white bars) or with (black bars) presence of clofazimine $(1.5-7.5 \mu \mathrm{g} / \mathrm{ml})$. For comparison, the effect of clofazimine on hemolysis is shown (grey bars). ${ }^{* * *}(\mathrm{p}<0.001), \#(\mathrm{p}<0.05)$ indicates significant difference from the absence of clofazimine (ANOVA).

A

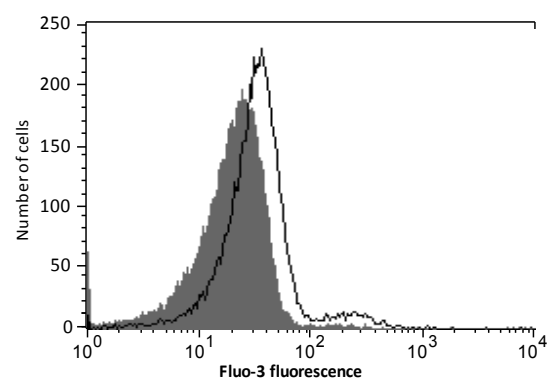

B

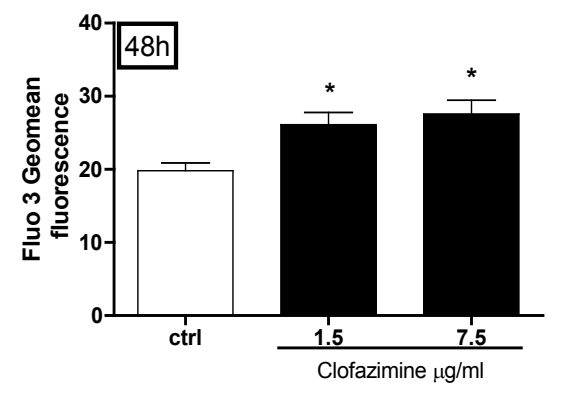

Fig. 2. Effect of clofazimine on erythrocyte $\mathrm{Ca}^{2+}$ activity. (A). Original histogram of Fluo3 fluorescence in erythrocytes following exposure for 48 hours to Ringer solution without (grey area) and with (black line) presence of clofazimine $(1.5 \mu \mathrm{g} / \mathrm{ml})$. (B). Arithmetic means \pm SEM $(\mathrm{n}=4)$ of the Fluo3 fluorescence (arbitrary units) in erythrocytes exposed for 48 hours to Ringer solution without (white bar) or with (black bars) clofazimine $(1.5-7.5 \mu \mathrm{g} / \mathrm{ml}) .{ }^{*}(\mathrm{p}<0.05)$ indicates significant difference from the absence of clofazimine (ANOVA). 
Fig. 3. $\mathrm{Ca}^{2+}$ sensitivity of clofazimine-induced phosphatidylserine exposure. Arithmetic means \pm SEM ( $n=4)$ of annexin-V-binding of erythrocytes after a 48 hours treatment with Ringer solution without (white bars) or with (grey and black bars) clofazimine $(1.5-7.5 \mu \mathrm{g} / \mathrm{ml})$ in the presence (left bars, $+\mathrm{Ca}^{2+}$ ) and absence (right bars, $-\mathrm{Ca}^{2+}$ ) of $\mathrm{Ca}^{2+}$. $*(\mathrm{P}<0.05), \quad * * * \quad(\mathrm{P}<0.001) \quad$ indicates significant difference from the absence of clofazimine, $\# \# \#(\mathrm{p}<0.001)$ indicates significant difference from corresponding value the presence of $\mathrm{Ca}^{2+}$ (ANOVA).

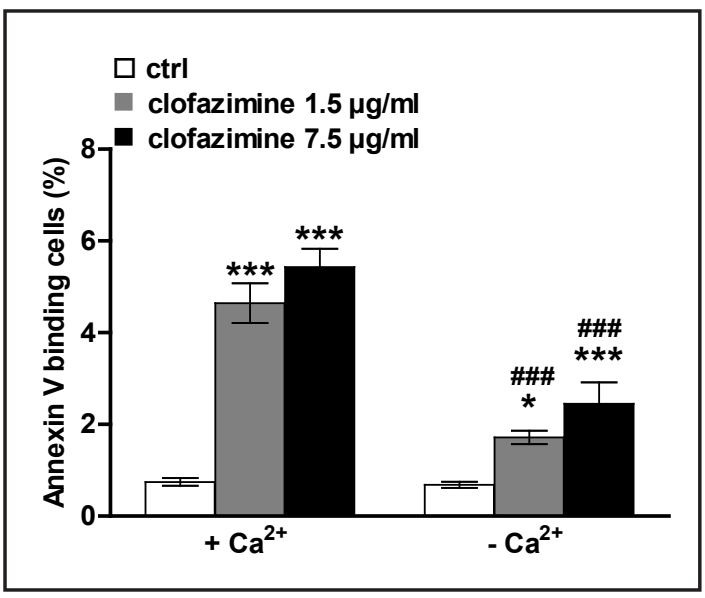

\section{A}

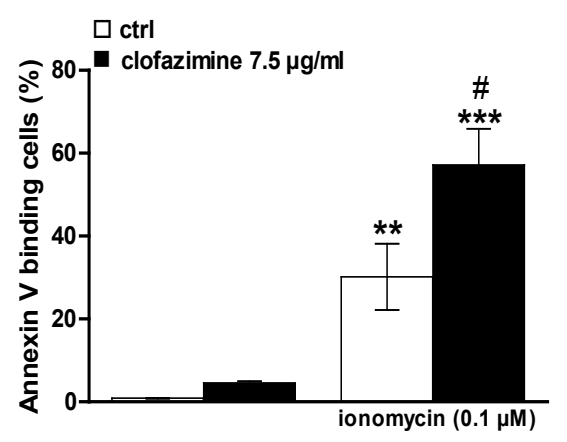

B

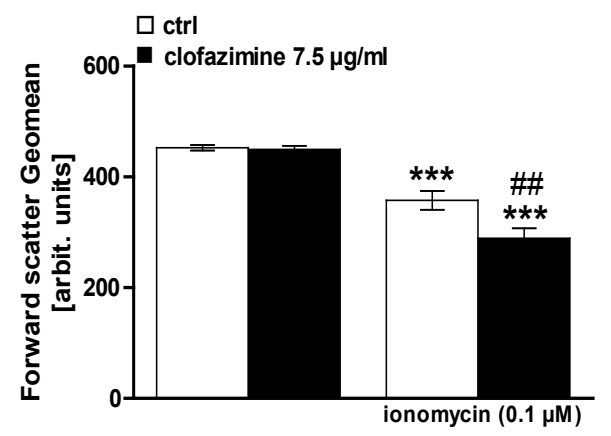

Fig. 4. Effect of clofazimine and $\mathrm{Ca}^{2+}$ ionophore ionomycin on phosphatidylserine exposure. (A) Arithmetic means \pm SEM of erythrocyte annexin-V-binding $(n=8)$ following incubation for 24 hours to Ringer solution without (white bars) or with (black bars) presence of clofazimine $(7.5 \mu \mathrm{g} / \mathrm{ml}$ ) in the absence (left bars) and presence (right bars, ionomycin) of calcium ionophore ionomycin $(0.1 \mu \mathrm{M})$. (B) Arithmetic means \pm SEM of erythrocyte forward scatter $(n=8)$ following incubation for 24 hours to Ringer solution without (white bars) or with (black bars) presence of clofazimine $(7.5 \mu \mathrm{g} / \mathrm{ml}$ ) in the absence (left bars) and presence (right bars, ionomycin) of calcium ionophore ionomycin $(0.1 \mu \mathrm{M}) .{ }^{* *}(\mathrm{p}<0.01),{ }^{* *}(\mathrm{p}<0.001)$ indicates significant difference from the absence of clofazimine, \# $(\mathrm{p}<0.05)$, \#\# $(\mathrm{p}<0.01)$ indicates significant difference from the absence of ionomycin (ANOVA).

A further series of experiments explored whether clofazimine-induced translocation of phosphatidylserine to the cell surface required entry of extracellular $\mathrm{Ca}^{2+}$. To this end, erythrocytes were incubated for 48 hours in the absence or presence of 1.5 or $7.5 \mu \mathrm{g} / \mathrm{ml}$ clofazimine, both in the presence or nominal absence of extracellular $\mathrm{Ca}^{2+}$. As illustrated in Fig. 3, removal of extracellular $\mathrm{Ca}^{2+}$ significantly blunted the effect of clofazimine on annexinV-binding. Nevertheless, even in the absence of extracellular $\mathrm{Ca}^{2+}$ clofazimine significantly increased the percentage of annexin-V-binding erythrocytes. Thus, eryptosis was in large part but not fully triggered by entry of extracellular $\mathrm{Ca}^{2+}$.

Additional experiments explored whether clofazimine was effective even in erythrocytes exposed to $\mathrm{Ca}^{2+}$ ionophore ionomycin. To this end, erythrocytes were exposed for 24 hours to $7.5 \mu \mathrm{g} / \mathrm{ml}$ clofazimine in the absence or presence of ionomycin $(0.1 \mu \mathrm{M})$. As illustrated in Fig. 4, clofazimine significantly augmented the effect of ionomycin on annexin-V-binding and forward scatter, an observation again pointing to an additional mechanism involved in the triggering of eryptosis by clofazimine.

\section{KARGER}



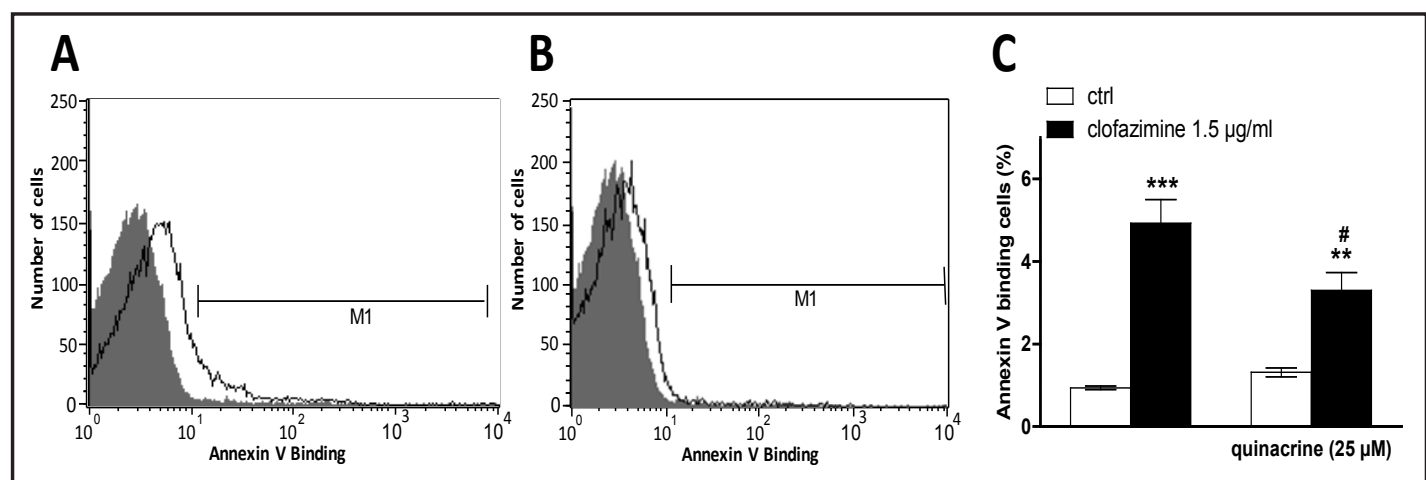

Fig. 5. Effect of Clofazimine on phosphatidylserine exposure in absence and presence of phospholipase $A_{2}$ inhibitor quinacrine. A,B. Original histogram of annexin-V-binding of erythrocytes following exposure for 48 hours to Ringer solution in the absence (grey area) and presence (black line) of 1.5 $\mu \mathrm{g} / \mathrm{ml}$ clofazimine in the absence (A) and presence (B) of phospholipase $A_{2}$ inhibitor quinacrine $(25$ $\mu \mathrm{M})$. (C) Arithmetic means \pm SEM of erythrocyte annexin-V-binding $(\mathrm{n}=8)$ following incubation for 24 hours to Ringer solution without (white bars) or with (black bars) presence of clofazimine $(5 \mu \mathrm{g} / \mathrm{ml})$ in the absence (left bars) and presence (right bars) of phospholipase $\mathrm{A}_{2}$ inhibitor quinacrine $(25 \mu \mathrm{M})$. $* * *(p<0.001)$ indicates significant difference from the absence of clofazimine , $\#(p<0.05)$ indicates significant difference from the absence of quinacrine (ANOVA).

Fig. 6. Effect of simultaneous $\mathrm{Ca}^{2+}$ removal and addition of quinacrine on clofazimine -induced phosphatidylserine exposure. Arithmetic means \pm SEM ( $\mathrm{n}=4$ ) of annexin-V-binding of erythrocytes after a 48 hours treatment with Ringer solution without (white bars) or with (black bars) clofazimine $(7.5 \mu \mathrm{g} / \mathrm{ml})$ in the presence (left bars), and absence (middle and right bars, $-\mathrm{Ca}^{2+}$ ) of $\mathrm{Ca}^{2+}$ and the absence (left and middle bars) and presence (right bars, $-\mathrm{Ca}^{2+}+$ quinacrine $)$ of $25 \mu \mathrm{M}$ quinacrine. $*(\mathrm{p}<0.05)$, $* * *(p<0.001)$ indicates significant difference from the absence of clofazimine, \#\#\#(p<0.001) indicates significant difference from corresponding value the presence of $\mathrm{Ca}^{2+}$ and absence of quinacrine (ANOVA).

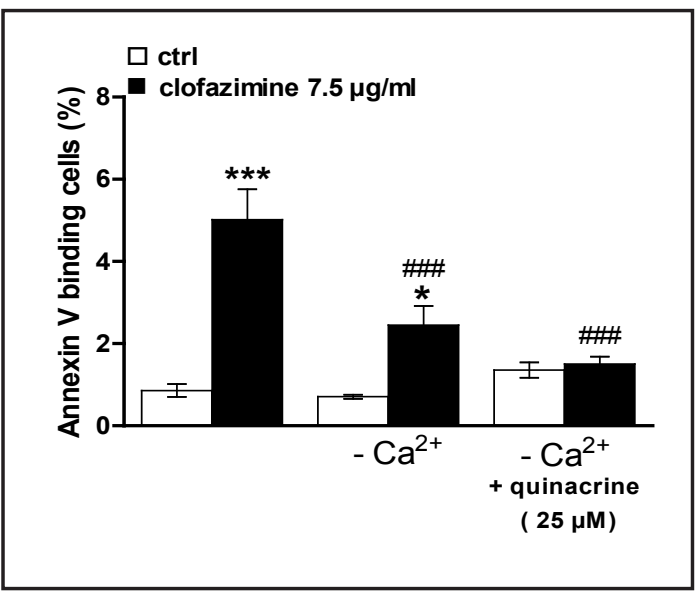

Fig. 7. Effect of clofazimine on erythrocyte ATP levels. Arithmetic means \pm SEM $(n=8)$ of cellular ATP (arbitrary units) in erythrocytes exposed for 48 hours to Ringer solution without (white bar) or with (black bar) clofazimine $(1.5 \mu \mathrm{g} / \mathrm{ml}){ }^{* *}(\mathrm{p}<0.01)$ indicates significant difference from the absence of clofazimine (t-test).

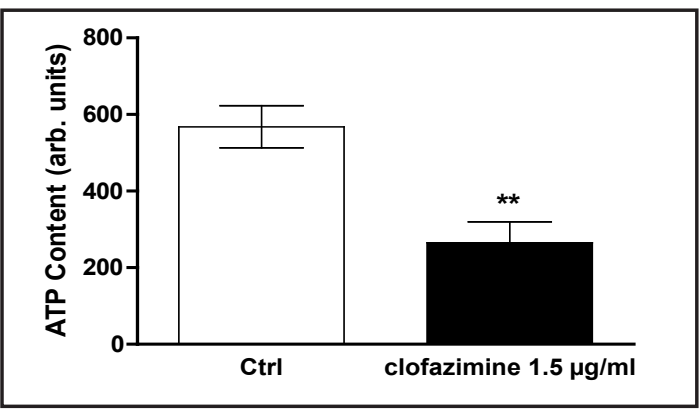

Triggers of eryptosis include oxidative stress. Reactive oxygen species (ROS) was thus quantified utilizing $2^{\prime}, 7^{\prime}$-dichlorodihydrofluorescein diacetate (DCFDA). As a result, the DCFDA fluorescence was similar following a 48 hours incubation without $(11.0 \pm 1.8$, $\mathrm{n}=4)$ and with $7.5 \mu \mathrm{g} / \mathrm{ml}(11.2 \pm 0.6, \mathrm{n}=4)$ clofazimine. In contrast, the fluorescence was significantly increased $(62.2 \pm 3.6, \mathrm{n}=4)$ following treatment with the oxidant tertbutylhydroperoxide (tBOOH) as a ppositive control. 


\section{Cellular Physiology Cell Physiol Biochem 2015;37:331-341 \\ \begin{tabular}{l|l|l}
\hline DOI: 10.1159/000430357 & C 2015 S. Karger AG, Basel
\end{tabular} \\ \begin{tabular}{l|l} 
and Biochemistry Published online: August 24, 2015 & www.karger.com/cpb
\end{tabular} \\ Officioso/Alzoubi/Manna/Lang: Clofazimine-Induced Eryptosis}

Additional experiments explored whether clofazimine-induced cell membrane scrambling was dependent on activation of phospholipase $\mathrm{A}_{2}$. To this end, erythrocytes were exposed for 48 hours to $1.5 \mu \mathrm{g} / \mathrm{ml}$ clofazimine in the absence or presence of the unselective phospholipase $\mathrm{A}_{2}$ inhibitor quinacrine $(25 \mu \mathrm{M})$. As illustrated in Fig. 5, the effect of clofazimine on annexin-V-binding was significantly blunted in the presence of phospholipase $A_{2}$ inhibitor quinacrine $(25 \mu \mathrm{M})$.

To test whether clofazimine-induced cell membrane scrambling was abolished by the combination of $\mathrm{Ca}^{2+}$ removal and addition of quinacrine, erythrocytes were exposed for 48 hours to $7.5 \mu \mathrm{g} / \mathrm{ml}$ clofazimine in the presence of Calcium, absence of calcium, or the combination of calcium absence and quinacrine presence. As illustrated in Fig. 6, the effect of clofazimine on annexin-V-binding was fully abolished by combined $\mathrm{Ca}^{2+}$ removal and quinacrine addition.

Eryptosis is further stimulated by energy depletion. A luciferin-luciferase assay was thus employed to determine the cytosolic ATP level. As illustrated in Fig. 7, a 48 hours exposure to $1.5 \mu \mathrm{g} / \mathrm{ml}$ clofazimine significantly decreased the cytosolic ATP level.

\section{Discussion}

The present observations disclose a novel effect of the riminophenazine clofazimine, i.e. the triggering of phospholipid scrambling of the erythrocyte cell membrane, a key event in suicidal erythrocyte death or eryptosis. The clofazimine concentration $(1.5 \mu \mathrm{g} / \mathrm{ml})$ required for stimulation of erythrocyte cell membrane scrambling was within the range of concentrations observed in vivo [4,54]. It must be kept in mind that the sensitivity of erythrocyte cell membrane scrambling to clofazimine may be enhanced in several clinical conditions associated with enhanced susceptibility to eryptosis, such as dehydration [41], hyperphosphatemia [52] chronic kidney disease (CKD) [30, 55-57], hemolytic-uremic syndrome [58], diabetes [59], liver failure [60], malignancy [61], sepsis [62] and Wilsons disease [63].

The effect of clofazimine on cell membrane scrambling was paralleled by an increase of cytosolic $\mathrm{Ca}^{2+}$ activity $\left(\left[\mathrm{Ca}^{2+}\right]_{\mathrm{i}}\right)$. More importantly, the effect of clofazimine on cell membrane scrambling was strongly blunted in the absence of extracellular $\mathrm{Ca}^{2+}$ and thus depended largely on $\mathrm{Ca}^{2+}$ entry. Nevertheless, even in the absence of extracellular $\mathrm{Ca}^{2+}$ clofazimine still increased cell membrane scrambling, an observation pointing to some additional mechanism.

Even though clofazimine increased $\left[\mathrm{Ca}^{2+}\right]_{i}$, it did not appreciably influence cell volume. An increase of $\left[\mathrm{Ca}^{2+}\right]_{i}$ were expected to activate $\mathrm{Ca}^{2+}$ sensitive $\mathrm{K}^{+}$channels with subsequent cell shrinkage due to $\mathrm{K}^{+}$exit, cell membrane hyperpolarization, $\mathrm{Cl}^{-}$exit and thus cellular loss of $\mathrm{KCl}$ with water [20]. It remains elusive, why clofazimine was without effect on cell volume.

The stimulation of cell membrane scrambling was further not paralleled by appreciable increases of reactive oxygen species (ROS), a known trigger of $\mathrm{Ca}^{2+}$ entry and subsequent cell membrane scrambling [21].

The clofazimine induced eryptosis was significantly blunted by phospholipase $\mathrm{A}_{2}$ inhibitor quinacrine [21]. Clofazimine has previously been shown to up-regulate phospholipase $\mathrm{A} 2$ in nucleated cells [1]. The combined $\mathrm{Ca}^{2+}$ removal and quinacerine addition fully abrogated the effect of clofazimine, indicating that the two mechanisms account for most of the stimulation of eryptosis by clofazimine.

Clofazimine further moderately decreased cellular ATP, an effect presumably contributing to the stimulation of cell membrane scrambling. Energy depletion is a well known stimulator of eryptosis [21].

Phosphatidylserine exposing erythrocytes are rapidly cleared from circulating blood, a mechanism ensuring disposal of defective erythrocytes prior to hemolysis [21]. Eryptosis thus prevents release of hemoglobin, which would otherwise be filtered in renal glomerula, precipitate in tubular fluid and thus occlude nephrons [64]. In malaria, Plasmodium-infected erythrocytes similarly expose phosphatidylserine, which fosters their clearance from circulating blood [21]. Triggering of cell membrane scrambling in infected erythrocytes may 


\section{Cellular Physiology Cell Physiol Biochem 2015;37:331-341 \begin{tabular}{c|c|c|}
\hline DOI: 10.1159/000430357 & O 2015 S. Karger AG, Basel
\end{tabular} and Biochemistry Published online: August 24, 2015 www.karger.com/cpb \\ Officioso/Alzoubi/Manna/Lang: Clofazimine-Induced Eryptosis}

thus favourably influence the clinical course of malaria [65]. Sickle-cell trait, beta-thalassemiatrait, Hb-C and G6PD-deficiency foster cell membrane scrambling of Plasmodium-infected erythrocytes and thus protect against a severe course of malaria [21, 66-68]. Iron deficiency [69], and treatment with lead [69], chlorpromazine [70] or NO synthase inhibitors [70] similarly sensitize erythrocytes to cell membrane scrambling and thus similarly counteract parasitemia. It is tempting to speculate that clofazimine may similarly foster cell membrane scrambling of Plasmodium-infected erythrocytes.

However, the accelerated clearance of phosphatidylserine exposing erythocytes from circulating blood leads to anemia, as soon as the loss of erythrocytes outcasts the generation of new erythrocytes [21]. Moreover, phosphatidylserine exposing erythocytes adhere to the vascular wall [71], trigger blood clotting and elicit thrombosis [72-74]. Stimulation of erythrocyte cell membrane scrambling may thus impair microcirculation [22, 72, 75-78].

\section{Conclusion}

Clofazimine triggers erythrocyte cell membrane scrambling. The effect is paralleled by and in part due to $\mathrm{Ca}^{2+}$ entry and energy depletion as well as abrogated by phospholipase $\mathrm{A}_{2}$ inhibitor quinacrine.

\section{Acknowledgements}

The authors acknowledge the meticulous preparation of the manuscript by Tanja Loch. The study was supported by the Deutsche Forschungsgemeinschaft and Open Access Publishing Fund of Tuebingen University.

\section{Disclosure Statement}

The authors state that they have nothing to disclose.

\section{References}

1 Arbiser JL, Moschella SL: Clofazimine: a review of its medical uses and mechanisms of action. J Am Acad Dermatol 1995;32:241-247.

2 Bennett S: Photosensitisation induced by clofazimine in a cat. Aust Vet J 2007;85:375-380.

3 Cariello PF, Kwak EJ, Abdel-Massih RC, Silveira FP: Safety and tolerability of clofazimine as salvage therapy for atypical mycobacterial infection in solid organ transplant recipients. Transpl Infect Dis 2015;17:111118.

4 Cholo MC, Steel HC, Fourie PB, Germishuizen WA, Anderson R: Clofazimine: current status and future prospects. J Antimicrob Chemother 2012;67:290-298.

5 Dey T, Brigden G, Cox H, Shubber Z, Cooke G, Ford N: Outcomes of clofazimine for the treatment of drugresistant tuberculosis: a systematic review and meta-analysis. J Antimicrob Chemother 2013;68:284-293.

6 Garrelts JC: Clofazimine: a review of its use in leprosy and Mycobacterium avium complex infection. DICP 1991;25:525-531.

7 Gopal M, Padayatchi N, Metcalfe JZ, O'Donnell MR: Systematic review of clofazimine for the treatment of drug-resistant tuberculosis. Int J Tuberc Lung Dis 2013;17:1001-1007.

8 Gurfinkel P, Pina JC, Ramos-e-Silva M: Use of clofazimine in dermatology. J Drugs Dermatol 2009;8:846851.

9 Holdiness MR: Clinical pharmacokinetics of clofazimine. A review. Clin Pharmacokinet 1989;16:74-85.

10 Hwang TJ, Dotsenko S, Jafarov A, Weyer K, Falzon D, Lunte K, Nunn P, Jaramillo E, Keshavjee S, Wares DF: Safety and availability of clofazimine in the treatment of multidrug and extensively drugresistant tuberculosis: analysis of published guidance and meta-analysis of cohort studies. BMJ Open 2014;4:e004143.

11 Kumar B, Kaur S, Kaur I, Gangowar DN: More about clofazimine--3 years experience and review of literature. Indian J Lepr 1987;59:63-74. 


\section{Cellular Physiology Cell Physiol Biochem 2015;37:331-341 \begin{tabular}{l|l} 
DOI: 10.1159/000430357 & (C) 2015 S. Karger AG, Basel
\end{tabular} and Biochemistry Published online: August 24, 2015 \\ Officioso/Alzoubi/Manna/Lang: Clofazimine-Induced Eryptosis}

12 Mathew BS, Pulimood AB, Prasanna CG, Ramakrishna BS, Chandy SJ: Clofazimine induced enteropathy--a case highlighting the importance of drug induced disease in differential diagnosis. Trop Gastroenterol 2006;27:87-88.

13 Pais AV, Pereira S, Garg I, Stephen J, Antony M, Inchara YK: Intra-abdominal, crystal-storing histiocytosis due to clofazimine in a patient with lepromatous leprosy and concurrent carcinoma of the colon. Lepr Rev 2004;75:171-176.

14 Ridder GJ, Fradis M, Lohle E: Cheilitis granulomatosa Miescher: treatment with clofazimine and review of the literature. Ann Otol Rhinol Laryngol 2001;110:964-967.

15 Freerksen E, Seydel JK: Critical comments on the treatment of leprosy and other mycobacterial infections with clofazimine. Arzneimittelforschung 1992;42:1243-1245.

16 Yoon GS, Sud S, Keswani RK, Baik J, Standiford TJ, Stringer KA, Rosania GR: Phagocytosed Clofazimine Biocrystals can Modulate Innate Immune Signaling by Inhibiting TNFalpha and Boosting IL-1RA Secretion. Mol Pharm 2015;10.1021/acs.molpharmaceut.5b00035.

17 Fukutomi Y, Maeda Y, Makino M: Apoptosis-inducing activity of clofazimine in macrophages. Antimicrob Agents Chemother 2011;55:4000-4005.

18 Pourgholami MH, Lu Y, Wang L, Stephens RW, Morris DL: Regression of Novikoff rat hepatocellular carcinoma following locoregional administration of a novel formulation of clofazimine in lipiodol. Cancer Lett 2004;207:37-47.

19 Lang PA, Kempe DS, Myssina S, Tanneur V, Birka C, Laufer S, Lang F, Wieder T, Huber SM: PGE(2) in the regulation of programmed erythrocyte death. Cell Death Differ 2005;12:415-428.

20 Lang PA, Kaiser S, Myssina S, Wieder T, Lang F, Huber SM: Role of Ca2+-activated K+ channels in human erythrocyte apoptosis. Am J Physiol Cell Physiol 2003;285:C1553-C1560.

21 Lang E, Qadri SM, Lang F: Killing me softly - suicidal erythrocyte death. Int J Biochem Cell Biol 2012;44:1236-1243.

22 Abed M, Towhid ST, Mia S, Pakladok T, Alesutan I, Borst O, Gawaz M, Gulbins E, Lang F: Sphingomyelinaseinduced adhesion of eryptotic erythrocytes to endothelial cells. Am J Physiol Cell Physiol 2012;303:C991999.

23 Lau IP, Chen H, Wang J, Ong HC, Leung KC, Ho HP, Kong SK: In vitro effect of CTAB- and PEG-coated gold nanorods on the induction of eryptosis/erythroptosis in human erythrocytes. Nanotoxicology 2012;6:847856.

24 Maellaro E, Leoncini S, Moretti D, Del Bello B, Tanganelli I, De Felice C, Ciccoli L: Erythrocyte caspase-3 activation and oxidative imbalance in erythrocytes and in plasma of type 2 diabetic patients. Acta Diabetol 2013;50:489-495.

25 Jilani K, Qadri SM, Lang F: Geldanamycin-induced phosphatidylserine translocation in the erythrocyte membrane. Cell Physiol Biochem 2013;32:1600-1609.

26 Vota DM, Maltaneri RE, Wenker SD, Nesse AB, Vittori DC: Differential erythropoietin action upon cells induced to eryptosis by different agents. Cell Biochem Biophys 2013;65:145-157.

27 Zappulla D: Environmental stress, erythrocyte dysfunctions, inflammation, and the metabolic syndrome: adaptations to CO2 increases? J Cardiometab Syndr 2008;3:30-34.

28 Zbidah M, Lupescu A, Jilani K, Lang F: Stimulation of suicidal erythrocyte death by fumagillin. Basic Clin Pharmacol Toxicol 2013;112:346-351.

29 Abed M, Herrmann T, Alzoubi K, Pakladok T, Lang F: Tannic Acid induced suicidal erythrocyte death. Cell Physiol Biochem 2013;32:1106-1116.

30 Ahmed MS, Langer H, Abed M, Voelkl J, Lang F: The uremic toxin acrolein promotes suicidal erythrocyte death. Kidney Blood Press Res 2013;37:158-167.

31 Ghashghaeinia M, Cluitmans JC, Toulany M, Saki M, Koberle M, Lang E, Dreischer P, Biedermann T, Duszenko M, Lang F, Bosman GJ, Wieder T: Age Sensitivity of NFkappaB Abundance and Programmed Cell Death in Erythrocytes Induced by NFkappaB Inhibitors. Cell Physiol Biochem 2013;32:801-813.

32 Alzoubi K, Honisch S, Abed M, Lang F: Triggering of Suicidal Erythrocyte Death by Penta-O-galloyl-beta-dglucose. Toxins (Basel) 2014;6:54-65.

33 Jilani K, Lang F: Carmustine-induced phosphatidylserine translocation in the erythrocyte membrane. Toxins (Basel) 2013;5:703-716.

34 Jilani K, Enkel S, Bissinger R, Almilaji A, Abed M, Lang F: Fluoxetine induced suicidal erythrocyte death. Toxins (Basel) 2013;5:1230-1243. 


\section{Cellular Physiology Cell Physiol Biochem 2015;37:331-341 \begin{tabular}{l|l} 
DOI: 10.1159/000430357 & (C) 2015 S. Karger AG, Basel
\end{tabular} www.karger.com/cpb \\ Officioso/Alzoubi/Manna/Lang: Clofazimine-Induced Eryptosis}

35 Lupescu A, Bissinger R, Jilani K, Lang F: Triggering of suicidal erythrocyte death by celecoxib. Toxins (Basel) 2013;5:1543-1554.

36 Lupescu A, Jilani K, Zbidah M, Lang F: Patulin-induced suicidal erythrocyte death. Cell Physiol Biochem 2013;32:291-299.

37 Abed M, Zoubi KA, Theurer M, Lang F: Effect of dermaseptin on erythrocytes. Basic Clin Pharmacol Toxicol 2013;113:347-352.

38 Arnold M, Lang E, Modicano P, Bissinger R, Faggio C, Abed M, Lang F: Effect of nitazoxanide on erythrocytes. Basic Clin Pharmacol Toxicol 2014;114:421-426.

39 Oswald G, Alzoubi K, Abed M, Lang F: Stimulation of suicidal erythrocyte death by ribavirin. Basic Clin Pharmacol Toxicol 2014;114:311-317.

40 Bissinger R, Malik A, Jilani K, Lang F: Triggering of Erythrocyte Cell Membrane Scrambling by Salinomycin. Basic Clin Pharmacol Toxicol 2014;10.1111/bcpt.12250

41 Abed M, Feger M, Alzoubi K, Pakladok T, Frauenfeld L, Geiger C, Towhid ST, Lang F: Sensitization of erythrocytes to suicidal erythrocyte death following water deprivation. Kidney Blood Press Res 2013;37:567-578.

42 Alzoubi K, Calabròa S, Bissinger R, Abed M, Faggio C, Lang F: Stimulation of Suicidal Erythrocyte Death by Artesunate. Cell Physiol Biochem 2014;34:2232-2244.

43 Arnold M, Bissinger R, Lang F: Mitoxantrone-induced suicidal erythrocyte death. Cell Physiol Biochem 2014;34:1756-1767.

44 Bissinger R, Fischer S, Jilani K, Lang F: Stimulation of Erythrocyte Death by Phloretin. Cell Physiol Biochem 2014;34:2256-2265.

45 Bissinger R, Lupescu A, Zelenak C, Jilani K, Lang F: Stimulation of eryptosis by cryptotanshinone. Cell Physiol Biochem 2014;34:432-442.

46 Bissinger R, Modicano P, Frauenfeld L, Lang E, Jacobi J, Faggio C, Lang F: Estramustine-induced suicidal erythrocyte death. Cell Physiol Biochem 2013;32:1426-1436.

47 Jacobi J, Lang E, Bissinger R, Frauenfeld L, Modicano P, Faggio C, Abed M, Lang F: Stimulation of erythrocyte cell membrane scrambling by mitotane. Cell Physiol Biochem 2014;33:1516-1526.

48 Lupescu A, Bissinger R, Herrmann T, Oswald G, Jilani K, Lang F: Induction of suicidal erythrocyte death by novobiocin. Cell Physiol Biochem 2014;33:670-680.

49 Lupescu A, Bissinger R, Warsi J, Jilani K, Lang F: Stimulation of erythrocyte cell membrane scrambling by gedunin. Cell Physiol Biochem 2014;33:1838-1848.

50 Malik A, Bissinger R, Calabro S, Faggio C, Jilani K, Lang F: Aristolochic Acid Induced Suicidal Erythrocyte Death. Kidney Blood Press Res 2014;39:408-419.

51 Tesoriere L, Attanzio A, Allegra M, Cilla A, Gentile C, Livrea MA: Oxysterol mixture in hypercholesterolemiarelevant proportion causes oxidative stress-dependent eryptosis. Cell Physiol Biochem 2014;34:10751089.

52 Voelkl J, Alzoubi K, Mamar AK, Ahmed MS, Abed M, Lang F: Stimulation of suicidal erythrocyte death by increased extracellular phosphate concentrations. Kidney Blood Press Res 2013;38:42-51.

53 Zhang R, Xiang Y, Ran Q, Deng X, Xiao Y, Xiang L, Li Z: Involvement of calcium, reactive oxygen species, and ATP in hexavalent chromium-induced damage in red blood cells. Cell Physiol Biochem 2014;34:1780-1791.

54 Nix DE, Adam RD, Auclair B, Krueger TS, Godo PG, Peloquin CA: Pharmacokinetics and relative bioavailability of clofazimine in relation to food, orange juice and antacid. Tuberculosis (Edinb) 2004;84:365-373.

55 Abed M, Artunc F, Alzoubi K, Honisch S, Baumann D, Foller M, Lang F: Suicidal erythrocyte death in endstage renal disease. J Mol Med (Berl) 2014;92:871-879.

56 Calderon-Salinas JV, Munoz-Reyes EG, Guerrero-Romero JF, Rodriguez-Moran M, Bracho-Riquelme RL, Carrera-Gracia MA, Quintanar-Escorza MA: Eryptosis and oxidative damage in type 2 diabetic mellitus patients with chronic kidney disease. Mol Cell Biochem 2011;357:171-179.

57 Polak-Jonkisz D, Purzyc L: Ca(2+) influx versus efflux during eryptosis in uremic erythrocytes. Blood Purif 2012;34:209-210; author reply 210.

58 Lang PA, Beringer O, Nicolay JP, Amon O, Kempe DS, Hermle T, Attanasio P, Akel A, Schafer R, Friedrich B, Risler T, Baur M, Olbricht CJ, Zimmerhackl LB, Zipfel PF, Wieder T, Lang F: Suicidal death of erythrocytes in recurrent hemolytic uremic syndrome. J Mol Med (Berl) 2006;84:378-388.

59 Nicolay JP, Schneider J, Niemoeller OM, Artunc F, Portero-Otin M, Haik G, Jr., Thornalley PJ, Schleicher 


\section{Cellular Physiology Cell Physiol Biochem 2015;37:331-341 \begin{tabular}{l|l|l} 
DOI: 10.1159/000430357 & (C) 2015 S. Karger AG, Basel
\end{tabular} and Biochemistry Published online: August 24, $2015 \quad$ www.karger.com/cpb \\ Officioso/Alzoubi/Manna/Lang: Clofazimine-Induced Eryptosis}

E, Wieder T, Lang F: Stimulation of suicidal erythrocyte death by methylglyoxal. Cell Physiol Biochem 2006;18:223-232.

60 Lang E, Gatidis S, Freise NF, Bock H, Kubitz R, Lauermann C, Orth HM, Klindt C, Schuier M, Keitel V, Reich M, Liu G, Schmidt S, Xu HC, Qadri SM, Herebian D, Pandyra AA, Mayatepek E, Gulbins E, Lang F, Haussinger D, Lang KS, Foller M, Lang PA: Conjugated bilirubin triggers anemia by inducing erythrocyte death. Hepatology 2015;61:275-284.

61 Qadri SM, Mahmud H, Lang E, Gu S, Bobbala D, Zelenak C, Jilani K, Siegfried A, Foller M, Lang F: Enhanced suicidal erythrocyte death in mice carrying a loss-of-function mutation of the adenomatous polyposis coli gene. J Cell Mol Med 2012;16:1085-1093.

62 Kempe DS, Akel A, Lang PA, Hermle T, Biswas R, Muresanu J, Friedrich B, Dreischer P, Wolz C, Schumacher U, Peschel A, Gotz F, Doring G, Wieder T, Gulbins E, Lang F: Suicidal erythrocyte death in sepsis. J Mol Med (Berl) 2007;85:273-281.

63 Lang PA, Schenck M, Nicolay JP, Becker JU, Kempe DS, Lupescu A, Koka S, Eisele K, Klarl BA, Rubben H, Schmid KW, Mann K, Hildenbrand S, Hefter H, Huber SM, Wieder T, Erhardt A, Haussinger D, Gulbins E, Lang F: Liver cell death and anemia in Wilson disease involve acid sphingomyelinase and ceramide. Nat Med 2007;13:164-170.

64 Harrison HE, Bunting H, Ordway NK, Albrink WS: The Pathogenesis of the Renal Injury Produced in the Dog by Hemoglobin or Methemoglobin. J Exp Med 1947;86:339-356.

65 Foller M, Bobbala D, Koka S, Huber SM, Gulbins E, Lang F: Suicide for survival--death of infected erythrocytes as a host mechanism to survive malaria. Cell Physiol Biochem 2009;24:133-140.

66 Ayi K, Giribaldi G, Skorokhod A, Schwarzer E, Prendergast PT, Arese P: 16alpha-bromoepiandrosterone, an antimalarial analogue of the hormone dehydroepiandrosterone, enhances phagocytosis of ring stage parasitized erythrocytes: a novel mechanism for antimalarial activity. Antimicrob Agents Chemother 2002;46:3180-3184.

67 Ayi K, Turrini F, Piga A, Arese P: Enhanced phagocytosis of ring-parasitized mutant erythrocytes: a common mechanism that may explain protection against falciparum malaria in sickle trait and beta-thalassemia trait. Blood 2004;104:3364-3371.

68 Cappadoro M, Giribaldi G, O'Brien E, Turrini F, Mannu F, Ulliers D, Simula G, Luzzatto L, Arese P: Early phagocytosis of glucose-6-phosphate dehydrogenase (G6PD)-deficient erythrocytes parasitized by Plasmodium falciparum may explain malaria protection in G6PD deficiency. Blood 1998;92:2527-2534.

69 Koka S, Huber SM, Boini KM, Lang C, Foller M, Lang F: Lead decreases parasitemia and enhances survival of Plasmodium berghei-infected mice. Biochem Biophys Res Commun 2007;363:484-489.

70 Koka S, Lang C, Niemoeller OM, Boini KM, Nicolay JP, Huber SM, Lang F: Influence of NO synthase inhibitor L-NAME on parasitemia and survival of Plasmodium berghei infected mice. Cell Physiol Biochem 2008;21:481-488.

71 Borst O, Abed M, Alesutan I, Towhid ST, Qadri SM, Foller M, Gawaz M, Lang F: Dynamic adhesion of eryptotic erythrocytes to endothelial cells via CXCL16/SR-PSOX. Am J Physiol Cell Physiol 2012;302:C644-C651.

72 Andrews DA, Low PS: Role of red blood cells in thrombosis. Curr Opin Hematol 1999;6:76-82.

73 Chung SM, Bae ON, Lim KM, Noh JY, Lee MY, Jung YS, Chung JH: Lysophosphatidic acid induces thrombogenic activity through phosphatidylserine exposure and procoagulant microvesicle generation in human erythrocytes. Arterioscler Thromb Vasc Biol 2007;27:414-421.

74 Zwaal RF, Comfurius P, Bevers EM: Surface exposure of phosphatidylserine in pathological cells. Cell Mol Life Sci 2005;62:971-988.

75 Closse C, Dachary-Prigent J, Boisseau MR: Phosphatidylserine-related adhesion of human erythrocytes to vascular endothelium. Br J Haematol 1999;107:300-302.

76 Gallagher PG, Chang SH, Rettig MP, Neely JE, Hillery CA, Smith BD, Low PS: Altered erythrocyte endothelial adherence and membrane phospholipid asymmetry in hereditary hydrocytosis. Blood 2003;101:46254627.

77 Pandolfi A, Di Pietro N, Sirolli V, Giardinelli A, Di Silvestre S, Amoroso L, Di Tomo P, Capani F, Consoli A, Bonomini M: Mechanisms of uremic erythrocyte-induced adhesion of human monocytes to cultured endothelial cells. J Cell Physiol 2007;213:699-709.

78 Wood BL, Gibson DF, Tait JF: Increased erythrocyte phosphatidylserine exposure in sickle cell disease: flowcytometric measurement and clinical associations. Blood 1996;88:1873-1880. 